\title{
Metode User Centered Design dalam Merancang Tampilan Antarmuka Ecommerce Penjualan Pupuk Berbasis Website Menggunakan Aplikasi Balsamiq Mockups
}

\author{
Fata Nidaul Khasanah ${ }^{1}$, Syahbaniar Rofiah ${ }^{2}$, Didik Setiyadi ${ }^{3}$ \\ ${ }^{1,3}$ Program Studi Teknik Informatika, STMIK Bina Insani -Jalan Siliwangi No.6 Bekasi 17114 \\ ${ }^{2}$ Program Studi Manajemen Informatika, STMIK Bina Insani -Jalan Siliwangi No.6 Bekasi 17114 \\ E-mail: fatanidaul@gmail.com
}

\begin{abstract}
ABSTRAK
Salah satu penghasil sampah diantaranya adalah di daerah pemukiman warga. Jenis sampah yang di sekitar pemukiman warga tujuh puluh lima persen berupa sampah organik yang berasal dari sisa makanan dan daun kering. Jenis sampah oragnik apabila diolah akan menghasilkan suatu produk yang nantinya memiliki nilai jual, misalnya pupuk. Metland Tambun Cluster Fontania Bekasi merupakan pihak mitra dimana pada pemukiman tersebut telah melakukan pengolahan sampah daun kering menjadi pupuk cair. Adapun permasalahan yang terdapat pada pihak mitra, yaitu belum adanya suatu media yang dapat membantu untuk memasarkan hasil produksi pupuk cair yang dihasilkan. Oleh karena itu tujuan dari kegiatan ini untuk membantu pihak mitra memasarkan hasil produksi pupuk cair dengan melakukan perancangan tampilan antarmuka pengguna ecommerce penjualan pupuk berbasis website menggunakan metode user centered design. Perancangan tampilan antarmuka pengguna ecommerce dibuat menggunakan aplikasi balsamiq mockups 3. Tahapan dari metode user centered design terdiri dari plan the human centered process, specify the context of use, specify user and organizational requirements dan produce design solutions. Dengan menggunakan metode user centered design maka rancangan tampilan antarmuka pengguna yang dihasilkan berfokus kepada kebutuhan pengguna. Hasil rancangan tampilan antarmuka pengguna yang telah dibuat meliputi halaman utama, halaman profil, halaman kontak, halaman produk dan halaman galeri.
\end{abstract}

Kata kunci : balsamiq mocups 3; ecommerce; user centered design; penjualan pupuk; user interface

\section{ABSTRACT}

One of the waste producers are in the residential area of residents. The type of garbage around seventy five percent settlements is organic waste derived from leftover food and dried leaves. Type of garbage when processed will produce a product that later has a selling value, for example fertilizer. Metland Tambun Cluster Fontania Bekasi is a partner in which the settlement has been processing waste dried leaves into liquid fertilizer. The problem is on the partner, namely the absence of a media that can help to market the production result of liquid fertilizer produced. Therefore, the purpose of this activity to help partners market the production of liquid fertilizers by designing the view of the ecommerce user interface of the fertilizer-based sales website using the method of user centered design. The design of an ecommerce user interface is created using the Balsamiq mockups 3 app. The stages of the user centered design method consist of plan the human centered process, specify the context of use, specify user and organizational requirements and produce design solutions. Using the user centered design method, the resulting design of the user interface is produced focusing on the needs of the user. The design results of the user interface views that have been created include the main page, profile page, contact page, product page and Gallery page. 


\section{PENDAHULUAN}

Sampah merupakan material sisa yang terbuang atau dibuang dari aktivitas manusia maupun proses alam yang belum memiliki nilai ekonomis. Berdasarkan sifatnya sampah dibedakan menjadi dua jenis, yaitu sampah organik dan sampah anorganik. Sampah organik merupakan jenis sampah yang mudah membusuk, seperti sisa makanan, daun kering, sisa sayuran dan lainnya. Sampah organik apabila diolah nantinya dapat dijadikan menjadi pupuk kompos dan nantinya bisa memiliki nilai jual. Sampah anorganik merupakan jenis sampah yang tidak mudah membusuk, seperti plastik, kaca, kayu dan lain sebagainya. Sampah anorganik apabila diolah nantinya dapat dijadikan menjadi produk lainnya yang memiliki nilai jual (1).

Salah satu penghasil sampah diantaranya adalah di daerah pemukiman warga. Jenis sampah yang terdapat di sekitar pemukiman warga tujuh puluh lima persen berupa sampah organik yang berasal dari sisa makanan dan daun-daun kering, sedangkan sisanya berupa sampah anorganik (2). Sampah yang menumpuk di sekitar pemukiman warga saat ini hanya sebatas dibuang dan dibiarkan menumpuk begitu saja. Padahal untuk jenis sampah organik apabila dapat diolah dengan baik bisa memberikan nilai jual, salah satunya adalah apabila jenis sampah organik yang menumpuk di sekitar pemukiman warga dapat diolah yang nantinya bisa menjadi pupuk kompos sehingga bisa memberikan nilai jual. Pupuk merupakan bahan yang ditambhakan ke dalam tanah yang nantinya dapat mempengaruhi pertumbuhan tanaman yang berasal unsur-unsur esensial yang dihasilkan oleh pupuk. Berdasarkan bentuknya pupuk organik dibedakan menjadi dua, yaitu pupuk cair dan pupuk padat (3).

Metland Tambun Cluster Fontania Bekasi merupakan salah satu pemukiman penduduk yang menghasilkan sampah. Jenis sampah yang dihasilkan pada pemukiman tersebut diantaranya adalah sampah daun kering dan sampah sisa makanan. Dari sampah daun kering yang dikumpulkan terdapat salah satu penduduk yang dijadikan sebagai mitra yang berusaha untuk mengolah sampah di sekitar pemukiman agar tidak menumpuk begitu saja. Hal yang dilakukan oleh mitra tersebut adalah mengolah daun kering yang ada untuk dijadikan menjadi pupuk cair yang dapat menghasilkan manfaat baru, baik manfaat untuk memupuk tanaman di sekitar pemukiman warga atau bahkan dapat memberikan nilai jual bagi mitra dari hasil pengolahan sampah daun kering tersebut. Adapun permasalahan yang terjadi pada mitra adalah belum adanya suatu media yang dapat membantu untuk memasarkan hasil produksi pupuk cair yang dihasilkan dari olahan sampah daun kering.

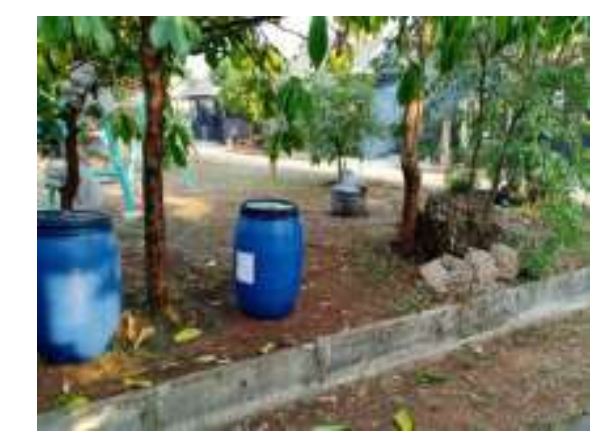

Gambar 1. Gambaran Lingkungan Mitra 
Saat ini peranan teknologi informasi berpengaruh dalam dunia ekonomi khusunya dalam hal pemasaran. Proses jual beli yang dilakukan melalui internet dikenal dengan ecommerce atau electronic commerce. Ecommerce biasanya berbasis website dimana didalamnya menyediakan layanan get and deliver. Ecommerce dapat dirasakan manfaatnya baik dari sisi penjual maupun pembeli. Manfaat yang dirasakan dari sisi penjual diantaranya biaya operasional yang lebih murah dan toko yang dimilikinya lebih dikenal oleh masyarakat luas karena barang yang dijual dapat diakses oleh siapa saja melalui internet. Sedangkan manfaat yang dirasakan dari sisi konsumen adalah pembeli dapat melihat informasi produk, melakukan proses pemesanan dan melakukan proses transaksi pembayaran dengan memanfaatkan internet yang dapat dilakukan dimana saja dan kapan saja (4). Kegagalan sebuah produk perangkat lunak ketika digunakan salah satunya dikarenakan pengguna tidak dapat berinteraksi dengan tampilan antarmuka dari perangkat lunak tersebut. Berdasarkan permasalahan tersebut maka perlu dilakukan sebuah pendekatan terhadap pengguna dalam mendesain tampilan antarmuka dari suatu produk perangkat lunak (5).

Metode user centered design merupakan sebuah pendekatan untuk pengembangan user interface dan pengembangan sistem (5). Metode user centered design memiliki konsep dimana pengguna sebagai pusat dari pengembangan sistem dan tujuan/sifat-sifat, konteks dan lingkungan sistem semua didasarkan dari pengalaman pengguna (6). Adapun tahapan dari metode user centered design sebagai berikut:

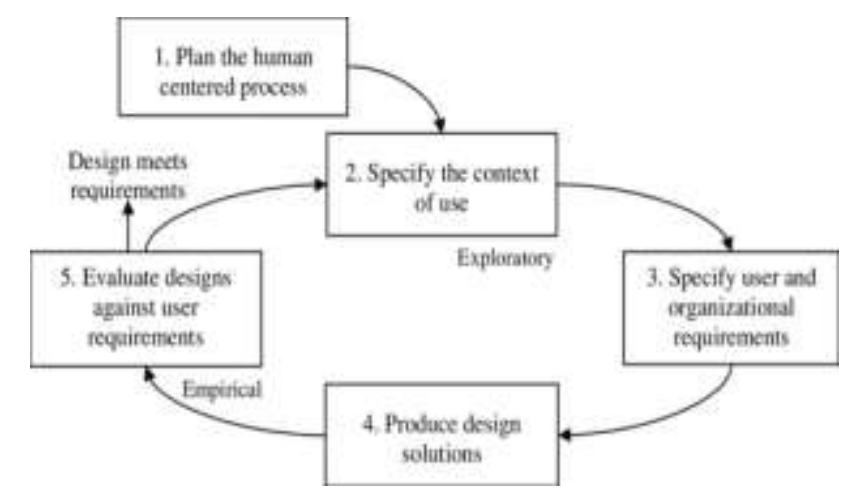

Sumber: Sabariah (2016)

Gambar 2. Metode User Centered Design

Berdasarkan permasalahan yang terjadi pada mitra maka diusulkan suatu gagasan penelitian yang bertujuan untuk membantu pihak mitra dalam memasarkan hasil produksi pupuk cair dari olahan daun kering. Dengan memanfaatkan perkembangan teknologi internet saat ini dapat dijadikan solusi untuk memasarkan hasil produksi mitra dengan membuat suatu ecommerce berbasis website sehingga nantinya pihak mitra dapat memasarkan hasil produksi secara online sehingga masyarakat luas dapat melihat produk yang dijual oleh pihak mitra. Adapun batasan dari penelitian ini yaitu hanya sebatas merancang suatu tampilan antarmuka pengguna dengan pendekatan metode user centered design. Perancangan tampilan antarmuka pengguna dibuat menggunakan perangkat lunak balsamiq mockups 3 . Balsamiq mockups 3 merupakan software yang digunakan untuk pembuatan tampilan antarmuka pengguna atau user interface sebuah aplikasi. Software ini merupakan salah satu aplikasi yang banyak digunakan oleh para perancang aplikasi (7).

Penggunaan metode user centered design digunakan untuk memudahkan pengguna dalam menggunakan fasilitas yang ada pada website ketika mencari 
informasi lowongan pekerjaan dan pengguna memiliki peranan penting dalam setiap proses metode user centered design (6). Metode user centered design digunakan dalam membangun aplikasi layanan manajerial di perguruan tinggi, dengan menggunakan metode tersebut dapat memicu kreatifitas dari pihak yang terlibat dalam menyusun spesifikasi kebutugan perangkat lunak yang diinginkan (8).

Ecommerce yang dibangun untuk membantu penjualan pupuk pada PT Pertani cabang Riau memberikan manfaat diantaranya membantu pengelolaan penjualan pupuk, pembukuan penjualan pupuk, laporan penjualan pupuk bahkan dapat dijadikan sebagai media promosi mengenai produk pupuk yang dihasilkan oleh perusahaan tersebut (9). Ecommerce yang dirancang dan diimplementasikan juga dilakukan pada program kemitraan masyarakat dengan usaha mikro kecil dan menengah (UMKM) batik di Jombang, ecommerce yang diusulkan bertujuan untuk memudahkan pihak UMKM dalam menjualkan produk batik Jombang ke seluruh kalangan dan dapat diketahui oleh masyarakat luas, ecommerce yang diusulkan berbasis website (10). Pembuatan akun ecommerce yang dilakukan oleh mitra bertujuan untuk mempermudah dalam melakukan transaksi jual beli minuman sri mawar anti aging, ecommerce yang dibuat oleh mitra antara lain Bukalapak, Shopee dan Tokopedia. Kegiatan tersebut dilakukan guna mengenalkan kepada mitra pemanfaatan digital marketing agar dapat mencetak masyarakat yang memiliki kemandirian dengan memanfaatkan teknologi (11).

\section{METODE KEGIATAN}

Program kemitraan masyarakat dilakukan di daerah Bekasi, pelakasanaan program kemitraan ini dilakukan dari adanya permasalahan yang terjadi pada mitra, dimana mitra memiliki produksi berupa pupuk cair dari olahan sampah daun kering, namun belum ada suatu media yang dapat membantu untuk memasarkan hasil produksi pupuk cair yang dihasilkan. Dengan memanfaatkan perkembangan teknologi internet saat ini dapat dijadikan solusi untuk membantu dalam memasarkan hasil produksi mitra dengan membuat suatu ecommerce berbasis website sehingga nantinya pihak mitra dapat menjual hasil produksi secara online dan masyarakat luas dapat melihat produk yang dijual oleh pihak mitra.

Adapaun tahapan yang dilakukan dalam merancang tampilan antarmuka ecommerce penjualan pupuk berbasis website dengan pihak mitra, diantaranya yaitu melakukan survei, merumuskan permasalahan, membuat tujuan, mengusulkan solusi dan diperolehlah hasil.

Tahap pertama yaitu survei. Pada tahap survei dengan mitra ini dilakukan bertujuan untuk mengetahui proses bisnis yang terjadi pada mitra. Pada tahapan ini dilakukan dengan cara observasi mengunjungi secara langsung untuk tempat mitra, yaitu di Metland Tambun Cluster Fontania Bekasi, selain itu juga dilakukan wawancara dengan pihak mitra yaitu pengganggas pembuatan pupuk cair dari olahan sampah daun kering.

Tahap kedua membuat perumusan masalah. Dari hasil survei mitra baik dengan cara observasi dan wawancara maka dibuatlah suatu perumusan masalah yang terjadi pada mitra. Adapun permasalahan yang terjadi adalah belum adanya suatu 
media yang dapat membantu untuk memasarkan hasil produksi pupuk cair yang dihasilkan dengan memanfaatkan teknologi, sehingga mengakibatkan kurang dikenalnya hasil produksi oleh masyarakat luas. Selanjutnya menentukan tujuan. Berdasarkan permasalahan yang terjadi maka dibuatlah suatu tujuan dalam program kemitraan masyarakat, tujuan dari program ini adalah membantu pihak mitra untuk memasarkan hasil produksi pupuk cair yang dihasilkan, agar nantinya hasil produksi dapat dikenal oleh masyarakat luas.

Tahap selanjutnya mengusulkan solusi penyelesaian. Setelah menentukan tujuan dari program kemitraan masyarakat maka dibuatlah suatu solusi penyelesaiannya. Dengan memanfaatkan perkembangan teknologi internet saat ini dijadikan solusi untuk membantu dalam memasarkan hasil produksi mitra dengan membuat suatu ecommerce berbasis website sehingga nantinya pihak mitra dapat menjual hasil produksi secara online. Dari hasil produksi yang dijual secara online diharapkan masyarakat luas dapat melihat produk yang dijual oleh pihak mitra ketika akses menggunakan internet. Adapun batasan dari penulisan ini yaitu hanya sebatas merancang suatu tampilan antarmuka pengguna dengan metode user centered design. Perancangan tampilan antarmuka pengguna dibuat menggunakan perangkat lunak balsamiq mockups 3. Plan the human centered process dilakukan dengan melakukan diskusi dengan pengguna agar menghasilkan suatu hasil yang berpusat kepada pengguna. Specify the context of use dilakukan dengan melakukan identifikasi pengguna yang nantinya akan menggunakan produk yang akan dihasilkan, dalam tahapan ini nantinya akan menjelaskan untuk apa serta dalam kondisi bagaimana pengguna akan menggunakan produk yang dihasilkan. Specify user and organizational requirements pada tahap ini dilakukan identifikasi kebutuhan pengguna dan kebutuhan organisasi selama membangun produk. Produce design solutions tahap ini dilakukan perancangan desain sebagai solusi dari produk yang akan dihasilkan yang sesuai dengan kebutuhan pengguna.

Tahap terakhir yaitu hasil. Hasil yang diperoleh dari penelitian ini berupa rancangan antarmuka ecommerce penjualan pupuk berbasis website menggunakan balsamiq mockups 3 dengan menggunakan metode user centered design.

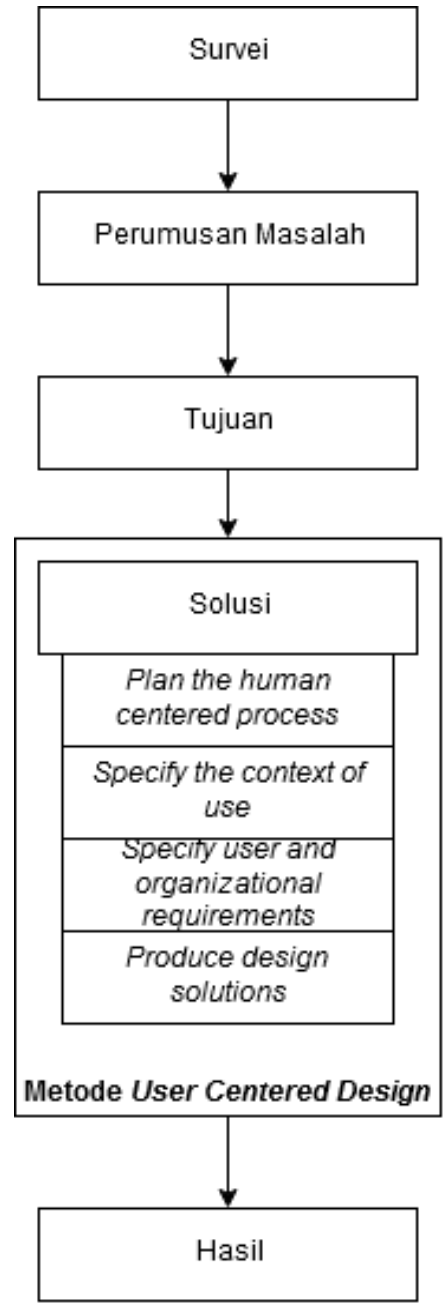

Gambar 3. Diagram Alir Proses Kemitraan Masyarakat 


\section{KARYA UTAMA}

Dalam merancang tampilan antarmuka pengguna perlu memperhatikan kebutuhan pengguna. Oleh karena itu dalam merancang tampilan antarmuka ecommerce penjualan pupuk berbasis website menggunakan metode user centered design. Metode ini digunakan agar menghasilkan suatu tampilan antarmuka pengguna ecommerce yang sesuai dengan kebutuhan pengguna.

Pada tahap plan the human centered process bertujuan untuk memastikan bahwa rancangan produk yang akan dihasilkan dapat memenuhi kebutuhan, keinginan dan harapan dari pengguna. Pada tahap ini dilakukan dengan melakukan studi literatur yang sesuai dengan topik program kemitraan masyarakat.

Tahap specify the context of use bertujuan untuk memahami dan menentukan konteks pengguna. Berdasarkan hasil survei dengan pihak mitra menunjukkan bahwa dalam memasarkan hasil produksi hanya dilakukan dengan cara menginformasikan dari mulut ke mulut dan tidak dapat dijangkau kepada masyarakat luas.

Tahap specify user and organizational requirements bertujuan untuk mengidentifikasi siapa saja pengguna dari sistem yang dibangun serta mengidentifikasi tugas apa yang akan dilakukan dari pengguna. Berdasarkan hasil wawancara dengan pihak mitra menunjukkan bahwa nantinya yang akan menggunakan aplikasi adalah pihak mitra yang nantinya akan mem-posting berupa hasil produksi pupuk cair yang dihasilkan oleh pihak mitra melalui aplikasi ecommerce berbasis website yang dirancang.

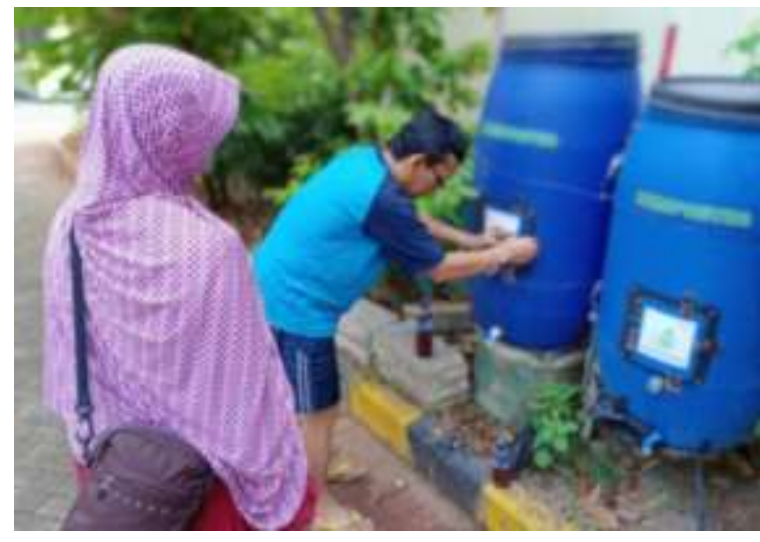

Gambar 4. Hasil Survei Dengan Pihak Mitra

Tahap produce design solutions bertujuan untuk memberikan solusi perancangan tampilan antarmuka yang dihasilkan. Adapun beberapa tampilan antarmuka pengguna yang dibuat dengan menggunakan aplikasi balsamiq mockups 3, diantaranya tampilan halaman menu utama, halaman profil, halaman produk pupuk cair yang dihasilkan, halaman kontak dan halaman galeri. Dalam merancang tampilan antarmuka pengguna menggunakan aplikasi balsamiq mockups 3, aplikasi ini dipilih karena berbasis cloud disertai dengan aplikasi desktop sehingga pengguna dapat dengan mudah dan cepat membuka rancangan tampilan antarmuka pengguna aplikasi ecommerce penjualan pupuk bebrbasis website.

Gambar 5 menunjukkan hasil rancangan tampilan antarmuka pengguna menggunakan balsamiq mockups 3 untuk halaman home. Pada gambaran hasil rancangan menunjukkan terdapat tiga bagian yaitu bagian atas, tengah dan bawah. Apada bagian atas atau yang dikenal header nantinya akan memunculkan slider yang berkaitan dengan pihak mitra berupa hasil produksi pupuk maupun galeri dari pihak 
mitra. Bagian tengah terdapat sidebar menu dari ecommerce serta isi konten yang berkaitan dengan pihak mitra. Dan terakhir bagian bawah atau dikenal dengan footer.

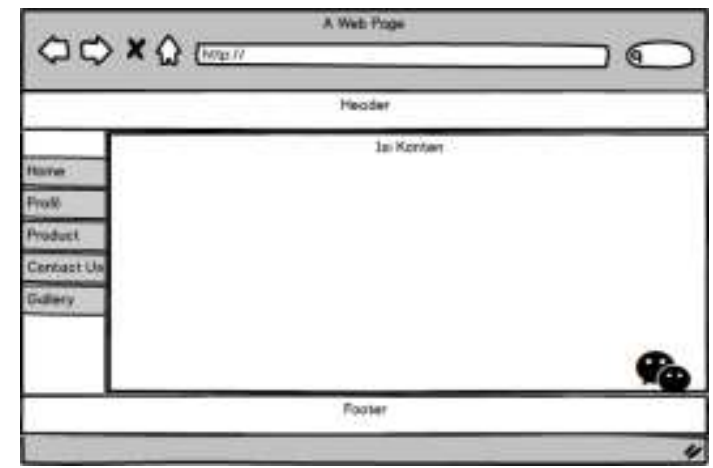

Gambar 5. Hasil Rancangan Tampilan Antarmuka Halaman Home

Gambar 6 menunjukkan hasil rancangan tampilan antarmuka pengguna untuk halaman profil. Pada halaman ini memunculkan profil yang berkaitan dengan sejarah berdirinya usaha pupuk yang dilakukan oleh pihak mitra program kemitraan kemasyarakatan.

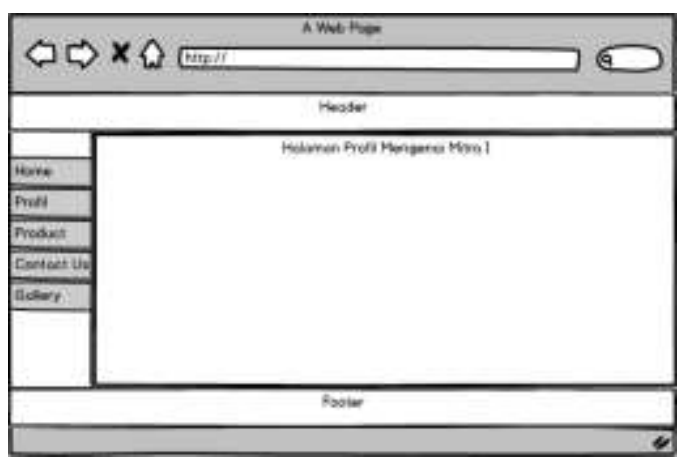

Gambar 6. Hasil Rancangan Tampilan Antarmuka Halaman Profile

Gambar 7 menunjukkan hasil rancangan tampilan antarmuka pengguna untuk halaman produk. Pada halaman produk akan menampilkan informasi produk yang dihasilkan oleh pihak mitra. Nantinya produk yang ditampilkan akan memunculkan informasi mengenai produk tersebut. Selanjutnya apabila konsumen ingin membeli produk yang dipilih akan diarahkan ke market place yang dihubungkan.

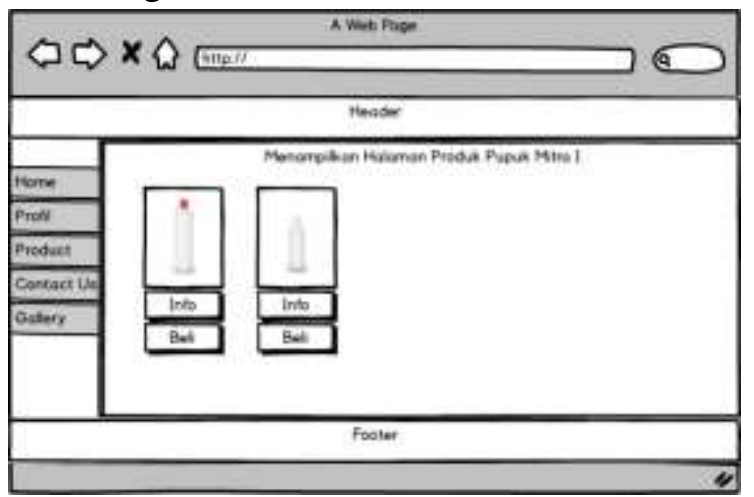

Gambar 7. Hasil Rancangan Tampilan Antarmuka Halaman Produk

Gambar 8 menunjukkan hasil rancangan tampilan antarmuka pengguna halaman kontak. Pada halaman ini akan memunculkan informasi mengenai kontak informasi pihak mitra, informasi yang dimunculkan dapat berupa nomor telepon, email serta alamat dari pihak mitra.

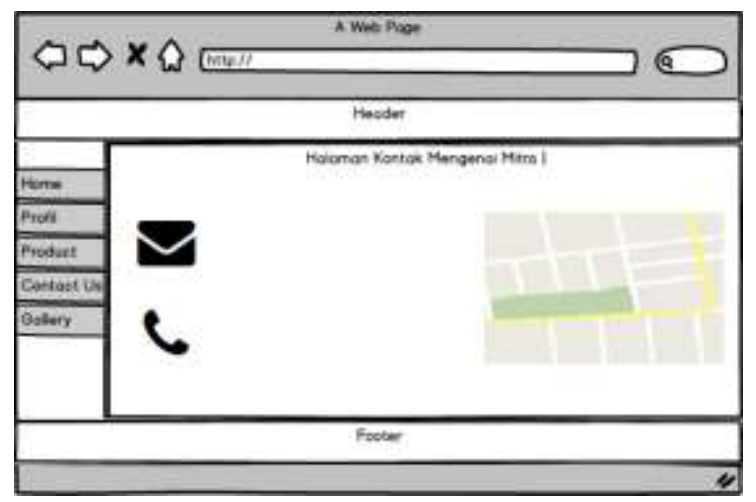

Gambar 8. Hasil Rancangan Tampilan

Antarmuka Halaman Kontak

Gambar 9 menunjukkan hasil rancangan tampilan antarmuka pengguna untuk halaman galeri. Pada halaman ini akan memunculkan informasi mengenai foto dan video galeri pihak mitra. Foto atau video yang dimunculkan berupa kegiatan 
yang dilakukan selama proses pembuatan pupuk dari olahan sampah daun kering.

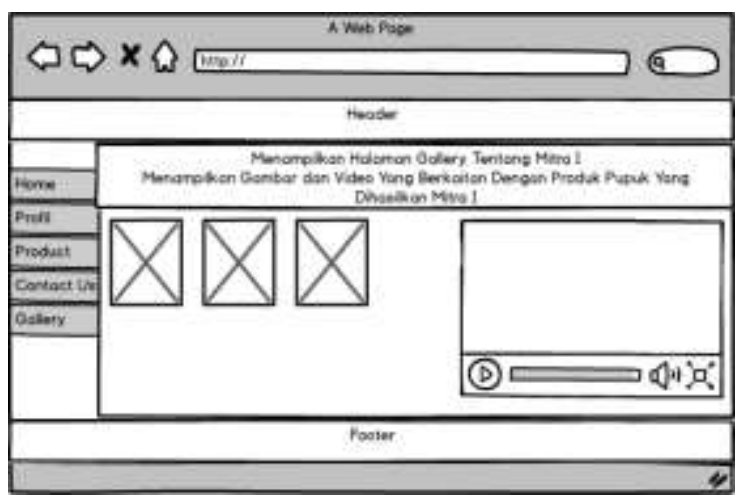

Gambar 9. Hasil Rancangan Tampilan Antarmuka Halaman Galeri

Gambar 10 menunjukkan hasil rancangan tampilan antarmuka pengguna untuk icon chat. Ketika pengguna aplikasi ecommerce ingin melakukan diskusi secara langsung dengan pihak mitra maka pada aplikasi ecommerce yang dirancang memberikan fasilitas chat. Dari fasilitas tersebut pengguna yang mengakses halaman website ecommerce akan diarahkan secara langsung ke aplikasi whatsapp agar pihak yang mengakses dapat berdiskusi secara langsung dengan pihak mitra.

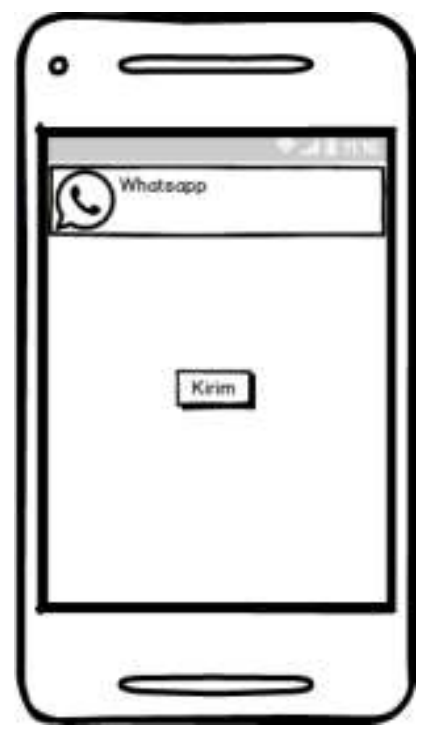

Gambar 10. Hasil Rancangan Tampilan Antarmuka Icon Chat

\section{ULASAN KARYA}

Dalam kegiatan kemitraan masyarakat ini memberikan manfaat bagi pihak mitra berupa rancangan tampilan antarmuka pengguna ecommerce penjualan pupuk. Kendala yang dihadapi pada pihak mitra yaitu kurangnya pengetahuan dalam membangun aplikasi berbasis website. Upaya yang dilakukan sebagai program kegiatan lanjutan yaitu membantu pihak mitra untuk membangun aplikasi ecommerce sesuai dengan hasil rancangan tampilan antarmuka pengguna yang telah dibuat. Selain itu juga dilakukan pelatihan untuk memberikan sharing knowledge dengan pihak mitra tentang penggunaan aplikasi yang dibuat yang nantinya dapat membantu pihak mitra menjual produk yang dapat dijangkau oleh masyarakat luas hanya dengan mengakses melalui internet.

Kelebihan dari hasil rancangan tampilan antarmuka aplikasi ecommerce yang dibuat adalah aplikasi yang dirancang berfokus kepada pengguna, namun hasil rancangan tampilan antarmuka ini belum dilakukan pengujian. Oleh karena itu kegiatan selanjutnya dapat melakukan pengujian terhadap hasil rancangan tampilan aplikasi ecommerce yang dibuat.

\section{DAMPAK DAN MANFAAT KEGIATAN}

Kegiatan ini memberikan manfaat kepada pihak mitra berupa rancangan tampilan antarmuka pengguna ecommerce berbasis website dengan menggunakan metode user centeerd design. Rancangan tampilan antarmuka yang dibuat menggunakan aplikasi balsamiq mockups 3 . Dengan menggunakan metode user centered design maka hasil rancangan tampilan antarmuka pengguna yang dihasilkan berfokus kepada kebutuhan pengguna. 
Berikut tabel perbandingan antara kondisi mitra sebelum dilakukan program kemitraan masyarakat dengan kondisi mitra setelah dilakukan program kemitraan masyarakat.

Tabel 1. Perbandingan Sebelum dan Sesudah Kegiatan Program Kemitraan Masyarakat

\begin{tabular}{|c|c|}
\hline $\begin{array}{ll}\text { Sebelum } & \text { Program } \\
\text { Kemitraan } & \\
\text { Masyarakat } & \end{array}$ & $\begin{array}{ll}\text { Sesudah } & \text { Program } \\
\text { Kemitraan } & \\
\text { Masyarakat } & \end{array}$ \\
\hline $\begin{array}{l}\text { Mitra belum } \\
\text { memiliki media } \\
\text { untuk memasarkan } \\
\text { hasil produksi secara } \\
\text { online. }\end{array}$ & $\begin{array}{l}\text { Dibuatnya rancangan } \\
\text { aplikasi ecommerce } \\
\text { yang membantu } \\
\text { pihak mitra dalam } \\
\text { memasarkan produk } \\
\text { yang dihasilkan } \\
\text { secara online. }\end{array}$ \\
\hline $\begin{array}{lr}\text { Mitra } & \text { belum } \\
\text { mengetahui } & \\
\text { bagaimana } & \text { cara } \\
\text { penggunaan } & \text { aplikasi } \\
\text { ecoomerce } & \text { yang } \\
\text { dibuat } & \end{array}$ & $\begin{array}{l}\text { Dilakukan } \\
\text { pendampingan } \\
\text { dengan pihak mitra } \\
\text { mengenai } \\
\text { penggunaan } \\
\text { ecommerce yang } \\
\text { telah dirancang. }\end{array}$ \\
\hline
\end{tabular}

Sumber: Hasil Penelitian (2019)

\section{KESIMPULAN}

Program kemitraan kemasyarakatan ini dilakukan untuk membantu pihak mitra dalam memasarkan hasil produksi pupuk cair dari olahan daun kering. Sebelum membangun aplikasi ecommerce penjualan pupuk berbasis website yang terpenting terlebih dahulu adalah merancang tampilan antarmuka pengguna dari aplikasi yang akan dihasilkan. Untuk itu hasil dari program ini berupa rancangan tampilan antarmuka pengguna ecommerce berbasis website dengan menggunakan metode user centeerd design. Tahapan yang telah dilakukan dari metode user centered design terdiri dari plan the human centered process, specify the context of use, specify user and organizational requirements dan produce design solutions. Rancangan tampilan antarmuka yang dibuat menggunakan aplikasi balsamiq mockups 3 . Dengan menggunakan metode user centered design maka hasil rancangan tampilan antarmuka pengguna yang dihasilkan berfokus kepada kebutuhan pengguna. Hasil rancangan tampilan antarmuka pengguna yang telah dibuat meliputi halaman utama, halaman profil, halaman kontak, halaman produk dan halaman galeri.

Dengan demikian adanya program kemitraan ini dapat memberikan kontribusi kepada pihak mitra berupa rancangan tampilan antarmuka aplikasi ecommerce berbasis website yang dapat digunakan oleh pihak mitra dalam memasarkan hasil produksi secara online dari kondisi mitra sebelumnya yang belum memiliki media online yang digunakan untuk memasarkan hasil produksi.

\section{PENGHARGAAN}

Penulis mengucapkan banyak terima kasih kepada Direktorat Riset dan Pengabdian Masyarakat Kementrian Riset, Teknologi dan Pendidikan Tinggi yang telah membiayai penelitian ini untuk skema Program Kemitraan Masyarakat Tahun Anggaran 2019. Keputusan Dirjen Penguatan Risbang Nomor 8/E/KPT/2019 tentang tentang Penerima Pendanaan Pengabdian kepada Masyarakat Tahun 2019.

\section{DAFTAR PUSTAKA}

1. Adiyanta YBS. Monitoring Prototip Mesin Pemilah Benda Berdasarkan Jenis Bahan. Yogyakarta; 2015.

2. Islamiyah M, Kala'lembang A. Desain dan Pengujian Alat Penghancur 
Sampah Organik Otomatis Berbasis Mikrokontroler Arduino Uno. J Electr Electron Control Autom Eng. 2018;3(2):199-204.

3. Hadisuwto S. Membuat Pupuk Kompos Cair. Agro Media; 2007.

4. Hidayat ZN, Choiri PBSM. Perancangan Dan Implementasi Sistem E-Commerce Dengan Menggunakan CMS Opencart Dalam Upaya Meningkatkan Penjualan Dan Pemasaran (Studi Kasus: UD. La Tanza Kecamatan Dau Malang). J Rekayasa Dan Manaj Sist Ind. 2014;2(1):219-29.

5. Sabariah MK, Effendy V, Junaedi D. Interaksi Manusia Dan Komputer. Bandung: Diandra Kreatif; 2016.

6. Sari R, Utami E, Amborowati A. Rancangan Lowongan Kerja Online Menggunakan Metode User Centered Design (Studi Kasus: Business Placement Center STMIK AMIKOM Yogyakarta). Creat Inf Technol J. 2016;3(1):62-72.

7. Krisnayani P, Arthana KR, Darmawiguna IGM. Analisa Usability
Pada Website Undiksha Dengan Menggunakan Metode Heuristic Evaluation. KARMAPATI (Kumpulan Artik Mhs Pendidik Tek Inform ISSN 2252-9063. 2016;5(2).

8. Ali E. Metode User Centered Design ( UCD ) Dalam Membangun Aplikasi Layanan Manajerial di Perguruan Tinggi. Sains dan Teknol Inf [Internet]. 2016;2(2):1-6. Available from: http://jurnal.stmik-amikriau.ac.id/index.php/satin/article/view/1 77/pdf

9. Novita R, Sari N. Sistem Informasi Penjualan Pupuk Berbasis ECommerce. Teknoif. 2015;3(2):1-6.

10. Dewi RS, Dewi OAC, Noviasri R. Perancangan dan Implementasi Sistem E-Commerce pada UMKM Batik di Kabupaten Jombang. Din J Pengabdi Kpd Masy. 2019;3(1):36-43.

11. Widiawati AM, Pratiwi AA, Bimandra G. Pelatihan Digital Marketing Strategy Untuk Mencapai Kemandirian Masyarakat. Din J Pengabdi Kpd Masy. 2019;3(1):147-57. 